\title{
Содействие торговле или упрощение процедур
}

Проанализированы положения Соглашения по упрощению процедур торговли, одобренного в результате 9-й Министерской конференции ВТО (Бали) в декабре 2013 г. и принятого в декабре 2014 г., а также рассмотрены значение данного соглашения для совершенствования таможенной системы России, Белоруссии и Казахстана, трудности его имплементации в существующих условиях.

Ключевые слова: содействие торговле, упрощение торговли, таможенные проиедуры, проиедуры транзита, таможенное администрирование, ВТО.

В конце 2013 г. произошло событие, с воодушевлением воспринятое всеми приверженцами и сторонниками Всемирной торговой организации. Одобрение Министерской конференцией так называемого Балийского пакета соглашений расценивалось как значимый прорыв в международной торговой системе, подтвердивший способность организации увязывать столь противоречивые интересы между разными странами в чувствительных вопросах торгово-экономических отношений. Первое достижение договоренностей после Уругвайского раунда и сразу по десяти вопросам действительно является большим прогрессом. Однако после заседания Генерального совета ВТО в июле 2014 г. в организации и вокруг нее царило настроение неопределенности и растерянности. Генеральный директор ВТО Роберто Азеведо, комментируя сложившуюся ситуацию, употреблял такие слова, как «кризис» и «тупик». Дело в том, что протокол о вступлении в силу одного из соглашений «Балийского пакета» - Trade Facilitation Agreement (TFA) - не получил своего одобрения на Генеральном совете ВТО в установленные для этого сроки в июле 2014 г., поскольку Индия, воспользовавшись правом вето, заблокировала его принятие. И вот долгожданная новость: Индия согласилась снять свои возражения в обмен на уступку со стороны США по вопросу оказания помощи сельскохозяйственным производителям ${ }^{2}$. Генеральный совет ВТО одобрил достигнутый компромисс 27 ноября текущего года.

1 Баландина Галина Владимировна - старший научный сотрудник Института прикладных экономических исследований Академии народного хозяйства и государственной службы при Президенте РФ (РАНХ и ГС). 
Настоящая статья посвящена названному Соглашению «Балийского пакета» - Trade Facilitation Agreement. В статье содержится результат анализа текста с оценкой того, как может отразиться на качестве таможенного администрирования полная имплементация всех его положений в законодательстве РФ и, что особенно важно, в отечественной правоприменительной практике в области таможенного дела.

Сначала немного о названии. Поскольку Соглашение только принято, официального перевода на русский язык его текста не существует. Версий перевода его названия несколько: соглашение о содействии торговле, соглашение об упрощении процедур торговли, соглашение об облегчении торговли, в зависимости от того, какой смысл вкладывается в понятие trade facilitation. Удивительно, но довольно устойчивое для торговых и таможенных правил и процедур понятие, которое используется международными организациями (например, Всемирной таможенной организацией (ВТамО), МВФ, ОЭСР, Всемирным банком, организациями и комитетами ООН), национальными правительствами, имеет несколько значений даже в оригинальной версии на английском языке. Для многих таможенных администраций trade facilitation традиционно является одной из задач наряду со сбором таможенных платежей, борьбой с незаконным ввозом наркотиков, обеспечением соблюдения законодательства, борьбой с таможенными правонарушениями ${ }^{1}$ и т.д. Вероятнее, в этом контексте содействие торговле уместно рассматривать именно как противовес осуществлению таможенного контроля. Международная конвенция об упрощении и гармонизации таможенных процедур (в редакции Брюссельского протокола 1999 г.), заключенная в рамках ВТамО, последующие ее рекомендации, наиболее известными из которых являются Рамочные стандарты безопасности, - как раз об этом. Как увязать, найти разумный компромисс между тем, чтобы обеспечить эффективность таможенного контроля и при этом не затруднять осуществление торговли, а наоборот, снижать и удешевлять все процедуры, связанные с трансграничным перемещением товаров.

Проект Соглашения об упрощении процедур торговли (для целей настоящей статьи будем использовать эту версию перевода названия проекта TFA как наиболее распространенную) содержит множество типовых и универсальных решений именно в той части, которая относится к содействию торговли. В глоссарии терминов ВТО содействие торговле (trade facilitation) определяется как снятие барьеров на пути движения товаров через границы (например, упрощение таможенных процедур) ${ }^{2}$.

1 См., например: http://ec.europa.eu/taxation_customs/customs/policy_ issues/trade_falicitation/ index_en.htm; http://www.cbp.gov/newsroom/local-mediarelease/2014-01-28-000000/cbp-puerto-rico-and-us-virgin-islands-fy2013-review 
После его одобрения на Балийской министерской конференции Соглашение об упрощении процедур торговли предполагалось включить в перечень многосторонних торговых соглашений, приводимый в Приложении 1А к Марракешскому соглашению об учреждении Всемирной торговой организации, т.е. включить его в перечень обязательных соглашений для всех членов ВТО.

Как же получилось, что Соглашение, основным предметом которого являются разного рода таможенные процедуры, попало в поле зрения Всемирной торговой организации, ведь традиционно вопросами таможенного администрирования занимается Всемирная таможенная организация? Наиболее очевидный ответ на этот вопрос состоит в том, что таможенные и другие административные формальности настолько увеличивают издержки, связанные с трансграничным перемещением товаров, что их упрощение, ускорение, стандартизация и унификация оцениваются как не менее важные, чем снижение таможенных тарифов или устранение нетарифных барьеров, вопросы.

По оценкам ОЭСР, новое Соглашение ВТО по упрощению процедур торговли может сократить торговые издержки почти на $14,5 \%$ для стран с низким уровнем доходов, и на $10 \%$ - для стран с высоким уровнем доходов 1 .

В Докладе Международного экономического форума содержатся еще более внушительные цифры. Эта международная организация пришла к выводу, что сокращение барьеров в цепочке поставок за счет улучшения администрирования и транспортно-коммуникационной инфраструктуры может привести к росту мирового ВВП на 4,7\%, а мирового экспорта - на $14,5 \%$. При этом, по подсчетам МЭФ, полная отмена тарифов может дать гораздо меньший эффект - 0,7\% роста мирового ВВП и $1,1 \%$ роста экспорта 2 .

До сих пор требования к таможенным формальностям и процедурам составляли незначительную часть правил ВТО. Генеральное соглашение о тарифах и торговле (ГАТТ) содержит общие принципы к организации таможенных формальностей с тем, чтобы они не являлись искусственными барьерами в торговле (ст. VIII), определяет некоторые стандарты транспарентности в этой области и предусматривает базовые требования к процедурам обжалования решений таможенных органов (ст. Х). Указанные статьи и легли в основу Соглашения об упрощении процедур торговли. Кроме того (что особенно важно для развивающихся стран, не имеющих выхода к морю), в Соглашение включены нормы, укрепляющие принцип свободы транзита, закрепленный в ст. V ГАТТ.

1 CM., например: http://ec.europa.eu/taxation_customs/customs/policy_issues/ trade_falicitation/index_en.htm; http://www.cbp.gov/newsroom/local-mediaelease/2014-01-28-000000/cbp-puerto-rico-and-us-virgin-islands-fy2013-review 
Статья VIII ГАТТ в части содействия торговле ограничивается декларативной нормой: «Договаривающиеся Стороны также признают необходимость сокращения до минимума объемов и сложности импортных и экспортных формальностей и сокращения и упрощения требований к импортной и экспортной документации».

Эта же ст. VIII ГАТT требует, чтобы таможенные сборы были ограничены по своей величине приблизительной стоимостью оказанных услуг и не использовались в протекционистских или фискальных целях. После того как Россия стала членом ВТО, максимальный размер таможенных сборов сократился более чем в три раза и составляет 30 тыс. руб. (ранее было 100 тыс. руб.). В ст. VIII ГАТT также устанавливается принцип соразмерности наказаний за таможенные правонарушения. «Никакая из Договаривающихся Сторон не должна налагать крупных штрафов за незначительные нарушения таможенных правил или процедурных требований. В частности, штраф за какие-либо пропуски или ошибки в таможенной документации, которые легко исправимы и явно были совершены не в целях обмана и не являются грубой небрежностью, не должен превышать размера, который необходим для того, чтобы служить только предупреждением». Кодекс РФ об административных правонарушениях (КоАП) не содержит каких-либо особых санкций в зависимости от обстоятельств, вследствие которых произошло правонарушение, если будет установлена вина нарушителя. Вероятно, для того, чтобы не допускать коррупционных явлений, российское законодательство не предоставляет возможностей при определении размера санкций учесть требования ГАТТ. На практике это приводит к тому, что если до подачи таможенной декларации импортер или его таможенный брокер не обнаружили ошибки в представляемых в таможню документах, санкция, например, за неправильно указанный артикул в таможенной декларации может составить до 200\% стоимости товаров. Зачастую импортер предпочитает, скорее, уничтожить товар, чем прийти в таможню и сознаться в допущенных ошибках. Поэтому в настоящее время в рамках выполнения мероприятий Дорожной карты «Совершенствование таможенного администрирования» ${ }^{1}$ обсуждается законопроект о внесении изменений в отдельные статьи гл. 16 КоАП с тем, чтобы обеспечить имплементацию данного принципа.

Меры, необходимые для обеспечения соблюдения таможенного законодательства, включены в перечень общих исключений ст. ХХ ГАТТ, правда, с оговоркой, что такие меры не должны быть средством произвольной или неоправданной дискриминации, скрытым ограничением международной торговли (подп. «d»).

Итак, текст Соглашения об упрощении процедур торговли основан на положениях ГАТТ, его ст. V, VIII и Х. 
Структурно Соглашение состоит из трех разделов.

Раздел I содержит собственно набор упрощений процедур торговли с разной степенью их обязательности для договаривающихся сторон. Кроме этого в данном разделе предусмотрены положения о таможенном сотрудничестве.

Раздел II содержит специальный и дифференцированный режим положений, позволяющих развивающимся и наименее развитым странам (НРС) определить, каким образом они будут реализовывать отдельные положения Соглашения. В этих целях все положения разд. 1 Соглашения сгруппированы в три категории:

- категория А соответствует положениям, которые договаривающаяся сторона будет выполнять при вступлении Соглашения в силу (в случае НРС - в течение одного года после вступления в силу);

- $\quad$ категория В соответствует положениям, которые член будет осуществлять после переходного периода после вступления в силу Соглашения;

- $\quad$ категория С соответствует положениям, которые член будет реализовывать после переходного периода после вступления в силу Соглашения и после получения технической помощи и поддержки от развитых стран (например, для создания необходимой инфраструктуры).

Раздел III содержит положения, согласно которым создается постоянный комитет по упрощению процедур торговли в рамках ВТО. В этом разделе также содержится требование к членам учредить национальный комитет по упрощению процедур торговли или определить механизм для содействия координации и реализации положений Соглашения.

Соглашение (разд. 1) предусматривает следующие ключевые элементы для облегчения торговли:

- транспарентность, прозрачность и открытость: публикация законов и других актов, регулирующих процедуры импорта, экспорта и транзита, включая информацию о пунктах пропуска, ставках пошлин и сборов, правил классификации и т.д.; доступность информации в Интернете о процедурах импорта, экспорта и транзита, включая рекомендации по практическим шагам для импорта, экспорта и транзита товаров; создание информационных центров для предоставления необходимых сведений участникам внешней экономической деятельности (ВЭД); предоставление информации о новых законах и иных нормативных актах до вступления их в силу с возможностью заинтересованных лиц дать свои комментарии; проведение регулярных консультаций между органами, действующими на границе, и заинтересованными лицами;

- стабильность действия правил: предоставление предварительных решений, которые должны быть действительны в течение разумного периода времени после выдачи, если законы, факты или обстоятельства не изменились; 
- защита прав и законных интересов участников ВЭД: право на обжалование любого административного решения в вышестоящем ведомстве, органе, независимом от лица или ведомства, которое приняло решение, и в суде; право на проведение повторного испытания товара; уведомление перевозчика или импортера о задержании товаров; наложение штрафов на лиц, ответственных за нарушение с соблюдением принципа соразмерности степени и тяжести нарушения; избежание конфликтов интересов при сборе штрафов и пошлин;

- $\quad$ ускорение таможенных формальностей: предварительная подача документов и сведений в электронном виде и предварительная обработка сведений до ввоза товаров; электронная оплата таможенных платежей; разделение выпуска и оплаты таможенных платежей и использование финансовых гарантий для обеспечения быстрого выпуска товаров; применение системы управления рисками при проведении таможенного контроля с быстрым выпуском товаров с низким уровнем риска; проверка соответствия законодательству после выпуска товаров (постаудит); дополнительные упрощения процедур торговли для уполномоченных экономических операторов; ускоренный выпуск для экспресс-грузов, перевозимых авиатранспортов и скоропортящихся товаров; сотрудничество ведомств на границе, включая проведение совместного контроля;

- сокращение требований к документаиии в связи с ввозом, вывозом и транзитом: признание электронных копий; использование международных стандартов при разработке требований к документации; однократность предоставления информации в электронном виде с технологией «единого окна»;

- $\quad$ снижение издержек торговли: отказ от предотгрузочной инспекции, добровольность в выборе таможенного брокера (посредника);

- упрощенные процедуры транзита: рекомендации раздельной инфраструктуры для транзитных перевозок; запрет на транзитные сборы, чрезмерные задержки и ограничения; предварительная обработка информации; применение генеральных (комплексных) финансовых гарантий (на несколько перевозок); ограничения на применение таможенного конвоя только крайними обстоятельствами;

- таможенное сотрудничество: взаимодействие между таможенными администрациями в части обмена информацией, взаимных запросов и предоставления информации с целью верификации представленных документов и сведений.

Нельзя не отметить, что многие положения Соглашения об упрощении процедур торговли перекликаются с рекомендациями ВТамО, ЕЭК ООН и ЮНКТАД (взаимодействие между таможенными органами и участниками ВЭД, участие таможенных брокеров в таможенных формальностях, таможенный контроль на основе управления рисками, «единое окно», финансовые гарантии, процедуры таможенного транзита, уполномоченный экономический оператор и т.д.). Однако, став положениями Соглашения 
об упрощении процедур торговли, соответствующие нормы будут уже иметь обязательный характер с возможностью членов прибегать к установленным ВТО процедурам урегулирования споров в случае их возникновения.

Еще одно важное замечание. В формулировках обязательств или рекомендаций для членов рассматриваемое Соглашение довольно скупо на детали. С одной стороны, это может свидетельствовать о том, что технические нюансы и подробности могут дополняться документами ВТамО или ЕЭК ООН. Например, гл. 6 Генерального приложения к Международной конвенции об упрощении и гармонизации таможенных процедур и рекомендации ВТамО к ней содержат довольно подробное описание методологии анализа рисков и управления ими для целей таможенного контроля, тогда как в Соглашении об упрощении процедур торговли этим вопросам посвящено небольшое количество подпунктов п. 4 ст. 7 с указанием на то, что:

- ч члены используют систему управления рисками по мере возможности;

- эта система должна применяться таким образом, чтобы избежать произвольной или необоснованной дискриминации или скрытого ограничения международной торговли;

- товары с низкой степенью риска освобождаются от проверок, за исключением проверок на случайной основе;

- при выборе критериев риска страны-члены учитывают код товара по Гармонизированной системе описания и кодирования товаров (ГС), описание товаров, страну происхождения и страну отправления, стоимость, законопослушание трейдеров и вид транспортного средства.

Конкуренция нормоположений Соглашения об упрощении процедур торговли и Международной конвенции об упрощении и гармонизации таможенных процедур может в будущем создать риски неопределенности для участников, в чем именно состоят их обязательства.

В Соглашении об упрощении процедур торговли довольно много положений, где строгие обязательства членов заменены в процессе переговоров на декларации об исполнении (как, например, в случае применения системы рисков обязательство сформулировано как выполнение по мере возможности) или рекомендации. Так, в ст. 3, устанавливающей требования в отношении принятия предварительных решений, обязательными остались только требования о предварительных решениях о классификации товаров и стране происхождения. По таким вопросам, как методы и критерии для определения таможенной стоимости, таможенные льготы, тарифные квоты, членам рекомендуется принимать предварительные решения. Понятно, что достичь согласия между всеми членами ВТО довольно трудно, поэтому в процессе переговоров компромиссы неизбежны. Ценность сведения в один документ всех известных современных способов ускорения процедур торговли снижается от наличия некоторых необязательных норм, но некритично. 
Актуальность и практическую ценность Соглашения об упрощении процедур торговли для России и других государств - членов Таможенного союза (с 1 января 2015 г. - Евразийского экономического союза, ЕАЭС) трудно переоценить. Многие положения Соглашения могли бы стать ориентиром для Таможенного кодекса будущего союза, работа над подготовкой текста которого находится в самом разгаре.

Государства, входящие в Таможенный союз, присоединились к Международной конвенции об упрощении и гармонизации таможенных процедур (18 мая 1973 г., Киото, далее - Киотская конвенция, конвенция) в редакции Брюссельского протокола от 26 июня 1999 г. По условиям конвенции государства обязаны в течение трех лет после присоединения к ней обеспечить выполнение принятых стандартов Генерального приложения (исключение составляют переходные стандарты, для которых этот срок составляет пять лет), а также специальных приложений. Для Российской Федерации конвенция вступила в силу 4 июля 2011 г. ${ }^{1}$, для Республики Казахстан 19 июня 2009 г., Республики Беларусь - 10 января 2011 г.

Киотская конвенция - важнейший международный договор в сфере таможенного дела, своего рода всемирный таможенный кодекс. На сегодняшний день участниками конвенции являются 85 государств. Конвенция определяет принципы таможенного администрирования, ключевыми из которых являются следующие:

- прозрачность и предсказуемость в деятельности таможенных органов;

- у упрощение и ускорение таможенных формальностей;

- упрощенные процедуры для уполномоченных лиц;

- максимальное использование информационных технологий;

- минимально необходимая степень таможенного контроля для обеспечения соблюдения таможенного законодательства;

- применение анализа рисков при проведении таможенного контроля;

- применение методов таможенного контроля, предусматривающих постаудит;

- координация деятельности таможенных органов и других контролирующих органов на границе;

- сотрудничество и партнерство с участниками торговли.

Эти же подходы являются ключевыми для Соглашения об упрощении процедур торговли.

Конвенция включает стандарты и переходные стандарты, т.е. положения, выполнение которых признается необходимым для достижения гармонизации и упрощения таможенных процедур и практики, а также Рекомендации по практическому

1 Федеральный закон от 3 ноября 2010 г. № 279-ФЗ. 
применению - положения, признаваемые как продвижение в деле гармонизации и упрощения таможенных процедур и практики, максимально широкое применение которых считается желательным. Стандарты содержатся в Генеральном и специальных приложениях. Генеральное приложение содержит свод положений, применимых ко всем таможенным процедурам и практике, упомянутым в конвенции. Специальное приложение содержит свод положений, применимых к одной или нескольким упомянутым в конвенции таможенным процедурам либо практике.

По условиям конвенции для договаривающейся стороны положения Генерального приложения обязательны, оговорок не допускается. Договаривающаяся сторона может принять одно специальное приложение или более либо одну его главу или более. Договаривающаяся сторона, принявшая Специальное приложение или его главу (главы), считается согласившейся на обязательность всех содержащихся в них стандартов, а также на обязательность всех содержащихся в них рекомендаций по практическому применению (далее - рекомендуемые правила), если только на момент принятия или в любое иное время после этого она не уведомит депозитария о рекомендации (рекомендациях) по практическому применению, в отношении которых она делает оговорки с указанием существующих расхождений между положениями ее национального законодательства и соответствующей рекомендацией (соответствующими рекомендациями) по практическому применению. Каждая договаривающаяся сторона, согласившаяся на обязательность специального приложения или его главы (глав), должна изучить возможность снятия любых своих оговорок к рекомендациям по практическому применению и в конце каждого трехлетнего периода, исчисляемого с даты вступления в силу настоящей конвенции для этой договаривающейся стороны, уведомить Генерального секретаря Совета таможенного сотрудничества (ныне - ВТамО) о результатах такого изучения, указав положения ее национального законодательства, не позволяющие, по ее мнению, отозвать оговорки ${ }^{1}$.

Генеральное приложение к конвенции содержит следующие главы.

Глава 1. Общие положения (сфера применения стандартов, переходных стандартов и определений, обязанность таможенной службы устанавливать и поддерживать официальные отношения консультативного характера с участниками внешнеторговой деятельности).

Глава 2. Определения (значения базовых определений, используемых для описания таможенных процедур в Генеральном и специальных приложениях к конвенции). 
Глава 3. Таможенное оформление (таможенная очистка) и другие таможенные формальности (компетенция таможенных органов и места их нахождения, требования к декларанту, его права, обязанность и ответственность, требования к декларации на товары, процедуры, связанные с ее принятием, регистрацией и проверкой, упрощенные процедуры для уполномоченных лиц, проверка товаров, процедуры выпуска товаров, последствия уничтожения товаров или отказа от них в пользу государства).

Глава 4. Пошлины и налоги (начисление, взимание и уплата пошлин и налогов, отсрочка уплаты пошлин и налогов, возврат уплаченных сумм пошлин и налогов).

Глава 5. Гарантии (требования к обеспечению уплаты таможенных пошлин, налогов, сумм гарантий (размеру обеспечения), генеральной гарантии).

Глава 6. Таможенный контроль (принципы выборочности таможенного контроля наосновеанализа рисков иуправления ими, требования кналичиюпроцедур контроля после выпуска товаров).

Глава 7. Применение информационных технологий (требования применять информационные технологии в случаях, когда это экономически выгодно и эффективно для таможенной службы и участников ВЭД деятельности, использовать электронные документы вместо документов на бумажных носителях).

Глава 8. Взаимоотношения между таможенной службой и третьими лицами (требования к регулированию условий деятельности посредников в проведении таможенных операций).

Глава 9. Информация, решения и предписания таможенной службы: информация общего характера (требования к наличию систем информирования о таможенном законодательстве); информация по конкретным вопросам (консультирование, связанное с применением таможенного законодательства); решения и предписания (обязанность таможенной службы принять решение по просьбе заинтересованного лица в установленные сроки, а также разъяснить причины принятого решения, если оно неблагоприятно для этого лица).

Глава 10. Жалобы по таможенным вопросам: право на обжалование (право любого лица обжаловать решение, действие или бездействие таможенного органа первоначально непосредственно в таможенных органах, в случае несогласия - в органе, независимом от таможенной службы, и в последней инстанции - в суде); форма жалобы и основания для ее подачи (предусматривается, что жалоба подается в письменной форме, на момент ее подачи заявитель вправе не представлять доказательства); рассмотрение жалобы (таможенная служба рассматривает жалобу в кратчайшие сроки, разъясняет обратившемуся лицу порядок обжалования решения по жалобе). 
ВТамО приняты рекомендации (Guidelines) ко всем главам Генерального приложения, кроме гл. 2 «Определение понятий», а также ко всем специальным приложениям и их главам. Эти рекомендации не являются частью юридического текста Киотской конвенции и не влекут каких-либо юридических обязательств для государства, присоединившегося к конвенции. В них содержатся пояснения к ее положениям, приводятся примеры лучших практик применения тех или иных положений различными государствами (таможенными администрациями). Таможенные администрации могут принимать и применять те рекомендации к положениям конвенции, которые наиболее соответствуют их конкретным условиям. Если эти рекомендации содержат более либеральные методы, чем того требует определенное положение или процедура конвенции, такое их применение может рассматриваться как предоставление более благоприятных условий в соответствии со ст. 2 конвенции.

Государства - члены Таможенного союза при присоединении к Киотской конвенции приняли на себя разный объем обязательств. Российская Федерация присоединилась только к ее Генеральному приложению, Республика Беларусь и Республика Казахстан помимо Генерального приложения взяли на себя также обязательства соблюдать различные главы специальных приложений. Республика Беларусь присоединилась к 11 приложениям, a Pe-

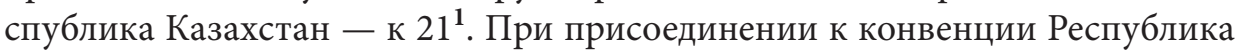
Беларусь заявила об обязательности применения 13 глав специальных приложений, в частности, гл. 1 и 2 Специального приложения А, гл. 1-3 Специального приложения В, гл. 1 Специального приложения С, гл. 1 Специального приложения D, гл. 1-3 Специального приложения Е, гл. 1 Специального приложения G и гл. 1 и 4 Специального приложения J. Республика Казахстан при присоединении к Конвенции заявила об обязательности 21 главы специальных приложений. По сути, для Казахстана обязательны все главы специальных приложений, кроме гл. 3 Специального приложения Е, гл. 3 Специального приложения F, главы 1 Специального приложения $\mathrm{H}$ и гл. 2 Специального приложения J.

Что касается Соглашения об упрощении процедур торговли, то для России и Армении его положения могут стать в скором времени обязательными как для членов ВТО, для Казахстана - как для будущего члена ВТО. В Таможенном союзе его члены стараются придерживаться принципа единого таможенного регулирования. Соответственно для единообразного применения Соглашения всеми его будущими участниками и Республикой Беларусь, которая не является членом ВТО, но входит в Таможенный союз, положения Соглашения должны быть имплементированы в общее таможенное законодательство - Таможенный кодекс Евразийского экономического союза.

1 http://www.wcoomd.org/en/about-us/legal-instruments/ /media/CE020DD763B 449669F6102264A061F3B.ashx 
Рассмотрим связанные с этим вопросы.

Институт уполномоченного экономического оператора (УЭО) введен в законодательство Таможенного союза в 2010 г. с принятием Таможенного кодекса Таможенного союза. Основные положения о присвоении статуса УЭО, об установлении и порядке применения специальных упрощений, предоставленных УЭО, содержатся в ст. 38-41 Таможенного кодекса Таможенного союза.

Институт УЭО является важным элементом системы упрощения таможенных формальностей и ускорения перемещения товаров через таможенные границы. Добросовестность и аккуратность (тщательность) в соблюдении необходимых процедур, связанных с перемещением товаров через таможенную границу, и ведении учета коммерческих операций в обмен на скорость и снижение некоторых административных требований, — таким образом можно описать основной принцип функционирования института УЭО. Для таможенных органов введение института УЭО позволяет сосредоточить свои ограниченные ресурсы на контроле поставок товаров, обладающих признаками рисков нарушения таможенного законодательства, следовательно, усиливается селективность подходов при совершении таможенных формальностей в интересах и бизнеса, и государства.

Рекомендации ВТамО к Киотской конвенции содержат положение о том, что все таможенные администрации должны ввести в действие как минимум две специальные процедуры и рассмотреть возможность внедрения других специальных процедур. Предусматривается, что таможенная служба должна проводить регулярные консультации с различными заинтересованными сторонами с тем, чтобы после введения в действие специальных процедур были реализованы максимальные выгоды для всех участников таможенных правоотношений, включая таможенную службу. В рекомендациях отмечается также, что применение специальных процедур благоприятно как для таможенной службы, так и для участников внешней торговли. Они облегчают движение товаров, создают заинтересованность в соблюдении таможенных правил и позволяют более эффективно использовать ресурсы таможенной службы. Специальные процедуры для уполномоченных лиц также способствуют внедрению современной концепции партнерства между таможенными органами, участниками экспортно-импортных операций и третьими лицами в сфере международной торговли.

Приобретая статус УЭО, в соответствии с таможенным законодательством Таможенного союза лицо может применять специальные упрощения, предусматривающие: временное хранение товаров на своих складах; выпуск товаров до подачи таможенной декларации; проведение отдельных таможенных операций, связанных с выпуском товаров, непосредственно на складах УЭО; ограничения на проведение плановых проверок при осуществлении таможенного контроля; освобождение от предоставления обеспечения 
уплаты таможенных платежей при транзите; применение единой декларации на товары, ввезенные/вывезенные за определенный период поставок; уплату таможенных платежей за определенный период поставок.

Соглашение об упрощении процедур торговли (п. 7.3 ст. 7) предусматривает необходимость установления для УЭО как минимум трех из следующих мер: - н низкие требования к документации и данным в соответствующих случаях;

- низкий уровень физических досмотров и проверок в соответствующих случаях;

- быстрое время выпуска в соответствующих случаях;

- отсрочка по оплате пошлин, платежей, налогов и сборов;

- применение комплексных или сниженных гарантий;

- единая таможенная декларация на все импортные или экспортные операции за определенный период;

- очистка товаров на территории уполномоченного оператора или в другом месте, санкционированном таможней.

Действующий Таможенный кодекс Таможенного союза содержит необходимые положения для применения всех перечисленных выше упрощений в отношении УЭО.

Таможенный кодекс Таможенного союза (ст. 38) устанавливает, что статус УЭО присваивается юридическому лицу, созданному в соответствии с законодательством государства — члена Таможенного союза, на территории которого этому лицу будет присвоен данный статус. Пунктом 2 ст. 41 указанного Таможенного кодекса установлено, что специальные упрощения, предусмотренные для УЭО, применяются только в случаях, если он вправе выступать декларантом товаров, в отношении которых предполагается применение таких специальных упрощений.

В соответствии с Рамочными стандартами безопасности и облегчения мировой торговли (приняты ВТамО 23 июня 2005 г.) статус УЭО могут получить производители, импортеры, экспортеры, брокеры, перевозчики, посредники, операторы портов, аэропортов, терминалов, складские операторы, дистрибьюторы - т.е. любые участники цепи поставки. Таким образом, законодательство Таможенного союза предусматривает более ограниченный круг лиц, которым может быть предоставлен статус УЭО. Подобные различия связаны прежде всего с тем, что права и обязанности участников цепочки поставок товаров таможенным законодательством Таможенного союза определяются по-иному, чем во многих странах — торговых партнерах России.

Таможенное законодательство Таможенного союза возлагает обязанности, связанные с выпуском товаров и уплатой таможенных платежей, исключительно на декларанта товаров. Посредничество в проведении таможенных операций допускается только через специальных уполномоченных 
на это лиц - таможенных представителей. Процедуры ввоза товаров на таможенную территорию и перемещения товаров под таможенным контролем в транзите сепарированы друг от друга. На каждом этапе таможенного оформления на разных лиц возлагаются обязанности по предоставлению, по сути, одной и той же информации о перемещаемых товарах. Таможенные операции в пунктах пропуска в связи с транзитной перевозкой одинаковы для всех лиц. Таможенное законодательство Таможенного союза и практика его применения предусматривают упрощения для отдельных лиц только на этапе декларирования и выпуска товаров. Отсюда и наделение статусом УЭО исключительно декларанта.

В Рамочных стандартах устанавливаются критерии, в соответствии с которыми компании, участвующие в цепи поставок товаров, могут получить специальный статус оператора по безопасности цепи поставок. Эти критерии охватывают такие аспекты, как:

- оценка угроз, наличие плана обеспечения безопасности с учетом оценки угроз;

- наличие плана коммуникационных мероприятий;

- принятие процедурных мер по недопущению попадания в международную цепь поставок товаров с нарушениями или без соответствующих документов;

- физическая безопасность зданий и сооружений, используемых в качестве погрузочных или складских площадок;

- безопасность контейнеров и товаров, средств транспорта;

- проверка персонала и защита информационных систем.

Признание участников цепи поставок УЭО определяется с учетом нескольких факторов: объем импорта, соответствие обычной деловой практике с точки зрения безопасности, стратегические угрозы, связанные с некоторыми географическими регионами, а также других факторов, имеющих отношение к рискам. Выбор факторов, которые будут иметь решающее значение, зависит от конкретных обстоятельств. Благодаря статусу УЭО компании получают минимальные льготы, которые могут фиксироваться в соглашении между ними и таможенными органами. Такие льготы могут включать:

- ускоренное совершение таможенных формальностей в отношении товаров незначительного риска;

- повышение уровня безопасности;

- оптимизацию издержек цепи поставок товаров за счет эффективного решения вопросов безопасности;

- повышение репутации организации, расширение деловых возможностей;

- более полное понимание таможенных требований и более тесный контакт между УЭО и таможенными органами.

Таможенное законодательство Таможенного союза не предусматривает такого упрощения для УЭО, как минимальные проверки. Предполагается, что 
учет статуса УЭО используется в системе анализа рисков и управления ими при выборе объектов таможенного контроля и степени его проведения.

В качестве одного из условий получения статуса УЭО Таможенный кодекс Таможенного союза (ст. 39) устанавливает предоставление обеспечения уплаты таможенных пошлин, налогов на сумму, эквивалентную 150 тыс. евро для компаний, «осуществляющих деятельность по производству товаров и (или) экспортирующих товары, к которым не применяются вывозные таможенные пошлины», и 1 млн евро - для всех остальных компаний. По сути, обеспечение уплаты таможенных платежей является генеральной (комплексной) финансовой гарантией, позволяющей УЭО осуществлять выпуск товаров до подачи таможенной декларации, фактически уплачивать таможенные платежи с отсрочкой, которая может составлять период до 40 дней. Однако установленный размер обеспечения не зависит от объема внешнеторговых операций, осуществляемых УЭО, видов товаров, которые им ввозятся, и ставок таможенных пошлин на эти товары, а также предоставленных ему видов упрощений. Это означает, что затраты на предоставление обеспечения в унифицированном размере могут различаться для разных УЭО. В зависимости от объема поставок, сумм подлежащих уплате таможенных платежей и упрощений, установленных для УЭО, размер обеспечения может быть более или менее обременительным для разных УЭО. Для малых и средних компаний данное требование может препятствовать получению ими статуса УЭО.

Таким образом, в части регулирования деятельности УЭО в законодательство Таможенного союза уже имплементированы положения Соглашения об упрощении процедур торговли. Вместе с тем очевидно, что совершенствование института УЭО невозможно в отрыве от реформирования и совершенствования иных институтов таможенного дела - внедрения механизма «единого окна», пересмотра прав и обязанностей лиц, участвующих в цепочке поставок товаров, совершения таможенных операций, развития института генерального обеспечения.

Информирование и консультирование. Важная роль в улучшении условий международной торговли и бизнес-климата в целом отводится информированности участников торговли о действующих правилах и их возможности получить консультацию по тем или иным вопросам, связанным с таможенным регулированием.

Таможенный кодекс Таможенного союза предусматривает обязанность таможенных органов осуществлять информирование о таможенном законодательстве Таможенного союза путем опубликования актов в официальных и иных печатных изданиях, доведения информации о них до всеобщего сведения по телевидению и радио с использованием информационных технологий, а также посредством иных способов распространения информации. Кроме того, предусматривается, что Комиссия Таможенного союза и тамо- 
женные органы обеспечивают беспрепятственный доступ лицам к информации о таможенном законодательстве Таможенного союза, размещенной на их официальных веб-сайтах в сети Интернет ${ }^{1}$. Кроме информирования о нормативных актах таможенные органы оказывают консультации по их применению, а также по иным вопросам, входящим в компетенцию данных органов. Консультирование осуществляется на бесплатной основе 2 .

Положения по информированию и консультированию в области таможенного дела содержатся в нескольких стандартах Генерального приложения к Киотской конвенции: «Таможенная служба обеспечивает беспрепятственный доступ любого заинтересованного лица ко всей относящейся к делу информации общего характера, касающейся таможенного законодательства (Стандарт 9.1); по запросу заинтересованного лица таможенная служба в возможно короткие сроки предоставляет максимально точную информацию по конкретным поставленным этим лицом вопросам, касающимся таможенного законодательства (Стандарт 9.4); в случае невозможности бесплатного предоставления информации таможенной службой любой сбор ограничивается приблизительной стоимостью оказанных услуг (Стандарт 9.7)».

Соглашение об упрощении процедур торговли содержит следующие основные обязательства в данной области. Члены ВТО должны своевременно опубликовывать в сети Интернет широкий спектр специализированной информации, относящейся к требованиям и процедурам таможенной очистки импортируемых и экспортируемых товаров. Данная информация должна включать процедуры, формы и документы, ставки таможенных пошлин и налогов, правила классификации и оценки стоимости товаров для целей таможенного оформления, правила относительно происхождения товаров, ограничения и процедуры при транзите, штрафные санкции, процедуры обжалования, торговые соглашения и правила администрирования тарифных квот.

Каждый член ВТО обязан создать и поддерживать работу точек получения справочной информации для предоставления ответов на запросы государственных органов и иных заинтересованных лиц, а также получения необходимых форм документов (п. 3 ст. 1 Соглашения).

Ранее в ст. Х ГАТТ упоминались лишь некоторые из перечисленных требований (такие как оценка таможенной стоимости и классификация для таможенных целей, ставки таможенных пошлин, налогов и прочих сборов). Дополнительные узко очерченные требования к прозрачности должны помочь

1 Статья 10 Таможенного кодекса Таможенного союза. 
коммерческим организациям получать актуальную информацию по всем импортно-экспортным процедурам и требованиям. Данное положение корреспондирует нормам, содержащимся в законодательстве РФ и Таможенного союза, согласно которым любые нормативно-правовые акты подлежат опубликованию только после их официального опубликования. Законодательство РФ предусматривает также возможности получения участниками ВЭД услуги по информированию и консультированию со стороны таможенных органов (в соответствии с Административным регламентом).

В Таможенном союзе в рамках ЕврАзЭС процедура получения консультаций в органах Таможенного союза не прописана. На практике компании или физические лица могут обратиться с письменным запросом в Евразийскую экономическую комиссию, однако регламент рассмотрения и ответа на такие запросы формально не установлен. В Евразийской экономической комиссии предусматриваются процедура консультаций и создание разного рода консультационных органов, однако в данных случаях речь идет о консультациях по инициативе комиссии, а не участников ВЭД. Установление единого пункта информирования и консультирования по общим вопросам таможенного законодательства Таможенного союза (вероятно, путем возложения данной функции на Евразийскую экономическую комиссию или ее структурное подразделение) позволило бы исключить имеющуюся практику, когда участники торговли получают в разных государствах членах Таможенного союза разную информацию по одному и тому же вопросу, связанному с применением законодательства Таможенного союза. В то же время получение запросов от участников торговли из различных государств - членов Таможенного союза позволило бы Евразийской экономической комиссии иметь информацию для обеспечения единообразного применения таможенного законодательства на всей единой таможенной территории Таможенного союза.

В вопросах консультирования важным аспектом является не только предоставление таможенными службами информации о действующих таможенных правилах, но и проведение консультаций при подготовке новых правил или изменении действующих. Один из ключевых стандартов Киотской конвенции (Стандарт 1.3 гл. 1 Генерального приложения) предусматривает обязанность таможенной службы устанавливать и поддерживать «официальные отношения консультативного характера с участниками внешней торговли в целях развития сотрудничества и содействия их участию во внедрении наиболее эффективных методов работы, согласующихся с национальным законодательством и международными договорами». В рекомендациях ВТамO к данному стандарту отмечается, что «прежде чем вносить какие-либо изменения, вводить новые процедуры или автоматизированные системы, таможенные службы должны согласовать данные действия с уполномоченными представителями торгового сообщества с тем, чтобы стороны могли осуществлять свою деятельность с учетом интересов друг друга». Обязанность предоставления участникам торговли и иным заинтересованным ли- 
цам возможности комментировать новые правила (изменения действующих правил) до их введения в действие, а также обязанность проводить консультации между органами и участниками торговли и иными заинтересованными лицами предусмотрена и Соглашением об упрощении процедур торговли (п. 2 и 3 ст. 2). Статья 2 предполагает, что члены берут на себя обязательства перед введением в действие новых или измененных законов либо нормативно-правовых требований, связанных с перевозкой, выпуском и таможенной очисткой товаров, проводить консультации с субъектами торговли и другими заинтересованными сторонами. Кроме того, должны проводиться регулярные совещания между пограничными органами, субъектами торговли и другими заинтересованными сторонами на территории государства.

В настоящее время законодательством РФ также предусмотрена возможность предварительного опубликования проектов нормативных актов, что позволяет заинтересованным лицам представлять свои замечания и предложения. Публичные консультации применяются в основном в ходе оценки проектов нормативно-правовых актов в рамках процедуры оценки регулирующего воздействия.

Предварительные решения являются инструментом, позволяющим обеспечить участникам торговли предсказуемость и стабильность при осуществлении ВЭД. ОЭСР, разработав комплекс из 12 показателей упрощения процедур торговли, считает, что наибольшим потенциалом снижения затрат на торговые операции обладают мероприятия по оптимизации процедур и предварительные решения ${ }^{1}$. По оценкам ОЭСР, меры по оптимизации процедур имеют потенциал снижения торговых издержек на 5,4\% и предварительные решения - на 3,7\%.

Таможенный кодекс Таможенного союза (ст. 52-57) предусматривает порядок принятия таможенными органами предварительных решений по вопросам классификации товаров по Товарной номенклатуре внешнеэкономической деятельности. Таможенный кодекс Таможенного союза также предусматривает возможность принятия предварительного решения по стране происхождения товаров, если это закреплено национальным законодательством государства — члена Таможенного союза (п. 4 ст. 58). Предварительные решения по классификации товаров по Товарной номенклатуре ВЭД принимаются таможенными органами по запросу заинтересованного лица. Срок действия предварительного решения - три года. Предварительное решение принимается таможенным органом того государства -

1 Moïsé E., Orliac T. and Minor P. Trade Facilitation Indicators: The Impact on Trade Costs // OECD Trade Policy Working Papers. 2011. No. 118. OECD Publishing. http://dx.doi.org/10.1787/5kg6nk654hmr-en;

http://www.wto.org/english/tratop_e/tradfa_e/case_studies_eloecd_paper_e.pdf 
члена Таможенного союза, в котором будет осуществляться выпуск товаров, и является обязательным при декларировании товаров на территории этого государства. Иными словами, предварительное решение по классификации товаров, принятое в одном государстве, не признается в другом государстве - члене Таможенного союза. Евразийская экономическая комиссия ведет сводный реестр предварительных решений по классификации товаров, принятых таможенными службами государств - членов Таможенного союза, и публикует его на своем официальном сайте.

В Киотской конвенции нет положений о принятии предварительных решений по таможенным вопросам. Международный стандарт, обязательный для Российской Федерации, относительно принятия предварительного решения о стране происхождения товаров содержит Соглашение по правилам происхождения (Марракеш, 15 апреля 1994 г.) ${ }^{1}$. В частности, подп. «f» ст. 3 указанного Соглашения предусмотрено следующее положение: «По запросу экспортера, импортера или любого лица, имеющего основательные мотивы, оценка происхождения товара сообщается в возможно короткие сроки, но не позднее 150 дней после запроса о таком решении, при условии, что все необходимые сведения о товаре были сообщены. Запросы о решении об определении страны происхождения товара принимаются до начала торговли данным товаром и в дальнейшем могут приниматься в любой момент. Такие решения должны оставаться в силе в течение трех лет, если факты и условия, включая правила происхождения, на основе которых они были сделаны, остаются сравнимыми...».

Статья 3 Соглашения об упрощении процедур торговли в части предварительных решений предусматривает следующие положения:

- каждый член должен выдать предварительное решение (письменное решение, предоставляемое членом заявителю до ввоза указанного в заявлении товара, в котором описан режим, который этот член обеспечит товару на момент ввоза) заявителю на основании его письменного запроса и в разумный срок;

- член может отказать в выдаче предварительного решения заявителю в случае, когда вопрос, затронутый в заявлении, находится на рассмотрении в деле заявителя в любом правительственном учреждении или апелляционном суде или либо заявитель уже имеет решение апелляционного трибунала или суда;

- предварительное решение должно быть действительно в течение разумного периода после его выдачи, если законы, факты или обстоятельства, связанные с ним, не изменились;

1 Соглашение является неотьемлемой частью Марракешского соглашения об учреждении Всемирной торговой организации от 15 апреля 1994 г. (вступило в силу для Российской Федерации 22 августа 2012 г.). 
- отозвать, изменить или признать недействительным предварительное решение «задним числом» (с приданием обратной силы) можно только в случае, когда оно было основано на неполной, неправильной, недостоверной или вводящей в заблуждение информации;

- предварительное решение принимается в отношении тарифной классификации товара и происхождения товара, а также может быть принято (сформулировано как рекомендация членам) по следующим вопросам:

1) соответствующему методу или критериям и их применению для определения таможенной стоимости при определенном наборе фактов;

2) применяемости требований члена о льготах или освобождении от уплаты таможенных пошлин;

3) применению требований члена в отношении квот, в том числе тарифных квот;

4) любым дополнительным вопросам, по которым член считает целесообразным выдать предварительное решение.

Очевидно, что Соглашение предусматривает предоставление участникам торговли гораздо больше возможностей для обеспечения предсказуемости ведения бизнеса. Соответственно целесообразно внести изменения и в таможенное законодательство Таможенного союза в части расширения круга вопросов, по которым можно получить предварительные решения. Кроме того, также важно обеспечить единообразие предварительных решений и распространение их действия на всю таможенную территорию Таможенного союза.

В части таможенных платежей и финансовых гарантий Соглашение об упрощении процедур торговли содержит важный пункт под названием «Разделение процедур выпуска и выдачи окончательного решения по таможенным пошлинам, налогам, платежам и сборам» (п. 3 ст. 7). Основной принцип для упрощения заключается в том, чтобы разрешать выпуск товаров до выдачи окончательного решения по таможенным пошлинам, платежам, налогам и сборам, если такое решение не дано до прибытия или по прибытии либо сразу после прибытия, настолько быстро, как это возможно, а также при условии, что все другие нормативные требования были выполнены. Предусмотрено, что как условие такого выпуска член может потребовать:

- уплату таможенных пошлин, налогов, платежей и сборов, определенных до или по прибытии товаров, и гарантию на любое количество, пока не определенное, в форме поручительства, залога или другого соответствующего инструмента, предусмотренного его законами и положениями; или

1 В проекте Таможенного кодекса будущего ЕАЭС таможенными службами трех стран предложена следующая норма: предварительное решение можно отменить с момента его выдачи, если при его принятии была допущена ошибка таможенными органами. Возможно, соответствующая норма Соглашения об упрощении процедур торговли поз-волит убедить регуляторов в очибочности такого подхода. 
- гарантию в форме поручительства, залога или другого соответствующего инструмента, предусмотренного его законами и положениями.

Таможенным кодексом Таможенного союза в ст. 82 определено, что таможенные пошлины и налоги уплачиваются в сроки, установленные для конкретных таможенных процедур. Например, в отношении товаров, помещаемых под таможенную процедуру выпуска для внутреннего потребления, «ввозные таможенные пошлины, налоги подлежат уплате... до выпуска товаров в соответствии с таможенной процедурой выпуска для внутреннего потребления ${ }^{1}$. Здесь следует напомнить, что срок выпуска товаров, установленный ст. 196 Таможенного кодекса, - один рабочий день, считая со дня после дня регистрации таможенной декларации. Этот срок может быть продлен до десяти рабочих дней с письменного разрешения руководителя таможенного органа для проведения или завершения форм таможенного контроля. На практике это означает, что товар удерживается таможенным органом до того момента, пока он не убедится, что сумма таможенных платежей, рассчитанная декларантом, определена верно, на основе правильно выбранной им ставки таможенной пошлины, соответствующей правильно выбранному коду Товарной номенклатуры и правильно определенной декларантом таможенной стоимости.

Киотская конвенция не содержит прямого указания на срок, в течение которого должны быть уплачены таможенные платежи, а говорит лишь, что такой срок должен быть определен национальным законодательством (Стандарт 4.8 Генерального приложения). Однако согласно Стандарту 4.2 таможенные пошлины начисляются в возможно короткие сроки после подачи декларации на товары или возникновения иных обязательств по уплате пошлин и налогов. Далее Стандарт 4.9 Генерального приложения устанавливает, что в случаях, «когда в национальном законодательстве предусматривается, что дата платежа может быть назначена после выпуска товаров, такая дата должна быть назначена не ранее чем через десять дней после выпуска товаров. Проценты в течение периода времени с даты выпуска и до даты платежа не взимаются».

Тема установления срока уплаты таможенных платежей получила дальнейшее развитие в рекомендациях к Киотской конвенции. Согласно рекомендациям к Стандарту 4.9 многие таможенные органы разрешают уплату таможенных платежей на периодической основе (обычно один раз в месяц), а также частями. При получении разрешения использовать процедуру уплаты на периодической основе обычно требуется обеспечение уплаты таможенных платежей. Для участников торговли, имеющих большой ежемесячный объем сделок, требования к объему гарантий могут быть сведены к минимуму путем разрешения им осуществлять в течение месяца промежуточные платежи.

1 Пункт $3 \mathrm{~cm} .211$, пункт 3 Таможенного кодекса Таможенного союза. 
Модернизированный Таможенный кодекс ЕС (МТК ЕС) предусматривает, что сроки уплаты таможенных пошлин составляют не более десяти дней со дня уведомления должника о наличии задолженности по уплате таможенных пошлин (ст. 72), допускается предоставление отсрочки и рассрочки уплаты таможенных пошлин. При этом п. 2 и 3 ст. 67 МТК ЕС предусматривает, что если сумма ввозных или вывозных пошлин, подлежащих уплате, равна сумме, указанной в таможенной декларации, то выпуск товаров таможенными органами рассматривается как уведомление должника о таможенной задолженности. В иных случаях должник уведомляется о таможенной задолженности в течение 14 дней с даты, когда таможенные органы могут определить сумму ввозных или вывозных пошлин, подлежащих уплате.

Как отмечалось выше, таможенное законодательство Таможенного союза устанавливает императивную норму о том, что таможенные платежи должны быть уплачены до выпуска товаров. Соответственно и таможенная стоимость, на основе которой рассчитываются таможенные платежи, также должна быть определена в эти сроки. Исключение сделано для случаев выпуска товаров под предоставление финансовых гарантий, если необходимо проведение дополнительной проверки заявленной таможенной стоимости, а также товаров, декларируемых лицами, которые имеют статус УЭО.

Предусмотренное Соглашением об упрощении процедур торговли требование устанавливать процедуры, в соответствии с которыми импортеру предоставляется возможность выпуска товаров до окончательного определения сумм таможенных пошлин, налогов, оценивается участниками торговли как одно из ключевых мероприятий, позволяющих реально ускорить совершение таможенных формальностей при импорте с одновременным повышением эффективности таможенного контроля и сокращения участия во внешнеэкономических операциях фирм-однодневок за счет внедрения института финансовых гарантий. Положительным эффектом внедрения данной нормы будет радикальное сокращение сроков выпуска, а значит - существенное снижение издержек участников ВЭД, в том числе за счет фактической ликвидации такой стадии таможенного оформления, как временное хранение товаров.

Предоставление предварительной информации о товарах и транспортных средствах предусмотрено ст. 42 Таможенного кодекса Таможенного союза: «Уполномоченные экономические операторы, перевозчики, в том числе таможенные перевозчики, таможенные представители и иные заинтересованные лица могут представлять таможенным органам в электронном виде предварительную информацию о товарах, предполагаемых к перемещению через таможенную границу, транспортных средствах международной перевозки, перемещающих такие товары, времени и месте прибытия товаров на таможенную территорию Таможенного союза или убытия с такой территории, пассажирах, прибывающих на таможенную территорию Таможенного союза или убывающих с такой территории». 
Положения Таможенного кодекса Таможенного союза конкретизируются в Соглашении о представлении и об обмене предварительной информацией о товарах и транспортных средствах, перемещаемых через таможенную границу Таможенного союза. В частности, предусматривается, что «обязательность представления предварительной информации определяется решением Комиссии Таможенного союза в зависимости от вида транспорта, на котором перемещаются товары», определяется объем сведений, подлежащих при предоставлении предварительной информации, и срок ее предоставления (не менее чем за два часа до ввоза товаров на таможенную территорию Таможенного союза).

Обязательное предварительное информирование о товарах, ввозимых автомобильным транспортом на территорию Таможенного союза, введено с 17 июня 2012 г. Решением Комиссии Таможенного союза от 9 декабря 2011 г. № 899 «О введении обязательного предварительного информирования о товарах, ввозимых на таможенную территорию Таможенного союза автомобильным транспортом». Данное решение предусматривает, что предварительная информация используется для ее сопоставления со сведениями, содержащимися в транспортных (перевозочных), коммерческих и (или) иных документах. По остальным видам транспорта подача предварительной информации осуществляется по усмотрению участников ВЭД.

Как инструмент анализа рисков и управления ими предоставление предварительной информации предусматривается Рамочными стандартами безопасности и облегчения мировой торговли ВТамО. В частности, Стандартом 6 «первой опоры» установлено следующее: «Для того чтобы обеспечить адекватную оценку рисков, таможенная администрация должна своевременно требовать предварительную электронную информацию о грузовых или контейнерных отправках». А вот что предусматривает Соглашение об упрощении процедур торговли в части предварительной информации. каждый член должен принимать или поддерживать процедуры, позволяющие подать импортную документацию и другую необходимую информацию, включая манифесты, чтобы начать обработку до прибытия товаров с целью ускорения выпуска товаров по их прибытии (подп. 1.1 п. 1 ст. 7).

Сравнительный анализ положений решения Комиссии, Рамочных стандартов и Соглашения об упрощении процедур торговли приводит к выводу, что при схожести требований предоставления предварительной информации цели ее использования различаются. Рамочные стандарты рекомендуют использование предварительной информации для выявления рисковых поставок. Соглашение уже не рекомендует, а требует использовать предварительную информацию для ускорения выпуска товаров, а решение Комиссии - для ее сравнения с документами на бумажных носителях. Кроме того, Рамочные стандарты содержат специальные 
положения о предварительной информации при осуществлении перевозок грузов и контейнеров морским транспортом. Предусматривается, что использование предварительной информации для выявления грузов и контейнеров повышенного риска может и должно осуществляться как можно раньше - в порту отгрузки или даже ранее, до начала загрузки морского судна. ВТамО рекомендует совместную работу таможенных администраций «для обеспечения максимальной безопасности и облегчения функционирования международной цепи поставок товаров по мере прохождения грузовых и контейнерных отправок по узловым точкам мировой торговой системы», что может являться эффективным противодействием террористическим посягательствам и другим формам транснациональной преступности. Таможенное законодательство Таможенного союза не предусматривает схожих положений.

\section{Использование системы управления рисками при проведении таможен-}

ного контроля. Основные положения системы управления рисками содержатся в гл. 6 Генерального приложения к Киотской конвенции:

- таможенный контроль сводится к минимуму, необходимому для обеспечения соблюдения таможенного законодательства (Стандарт 6.2);

- $\quad$ при проведении таможенного контроля таможенная служба использует систему управления рисками (Стандарт 6.3);

- таможенная служба применяет анализ рисков для определения лиц и товаров, включая транспортные средства, которые должны быть проверены, и степени такой проверки (Стандарт 6.4);

- таможенная служба принимает стратегию оценки степени соблюдения законодательства в целях поддержки системы управления рисками (Стандарт 6.5).

Аналогичные требования установлены в Соглашении об упрощении процедур торговли (п. 4 ст. 7): «Таможенные администрации должны применять, по мере возможности, управление рисками к таможенному контролю в отношении ввоза, вывоза и транзитных перевозок, усилить таможенный контроль партий товаров с высокой степенью риска и ускорить выпуск партий товаров с низкой степенью риска. При управлении рисками необходимо использовать соответствующие критерии избирательности, такие как, помимо прочего, товарный код, род товаров, страна происхождения, страна, из которой отгружены товары, стоимость товаров, соответствие участников торговли критериям добросовестности, тип транспортировки и цель нахождения товаров на таможенной территории. Таможенные администрации должны разрабатывать и применять принципы управления рисками таким образом, чтобы исключить необоснованную или неправомерную дискриминацию либо скрытые ограничения в отношении международной торговли». Соглашение также рекомендует, насколько это возможно, исключить двойной контроль при выпуске товаров между членами Таможенного союза, если такой контроль производится при ввозе в страну или при вывозе из страны. 
В Рамочных стандартах безопасности и облегчения мировой торговли ВТамО выделено четыре элемента, на которых должны основываться современные методы работы таможенных администраций. Это - прежде всего обязательство последовательно подходить к вопросам управления рисками с целью решения вопросов безопасности. Это - гармонизация требований в отношении предварительного электронного уведомления о грузе при входящих, исходящих и транзитных отправках и организация досмотров грузов повышенного риска таможенной администрацией страны отправки по обоснованному запросу таможенной администрации страны импорта. И наконец - это определение преимуществ, которые таможенные службы будут предоставлять компаниям, соблюдающим минимальные стандарты безопасности международной цепи поставок товаров. Данные основные подходы постоянно обновляются, дальнейшее развитие базовых принципов закреплено в различных документах ВТамО (руководствах, рекомендациях, иных документах).

Положение о том, что таможенные органы используют систему управления рисками при выборе объектов и форм таможенного контроля, закреплено в ст. 94 Таможенного кодекса Таможенного союза и развито далее в ст. 128, в соответствии с которой «таможенные органы применяют систему управления рисками для определения товаров, транспортных средств международной перевозки, документов и лиц, подлежащих таможенному контролю, форм таможенного контроля, применяемых к таким товарам, транспортным средствам международной перевозки, документам и лицам, а также степени проведения таможенного контроля». При этом стратегия и тактика применения системы управления рисками определяется законодательством государств - членов Таможенного союза.

Проведение таможенного контроля на основе анализа рисков является прогрессивной формой работы таможенных администраций, поскольку, с одной стороны, позволяет таможенной службе высвободить ресурсы для контроля наиболее проблемных поставок, а с другой стороны, добросовестные участники торговли, находящиеся в так называемой зоне низкого риска, могут рассчитывать на ускоренный выпуск своих поставок с минимальными мерами таможенного контроля.

Внедрение технологии «единого окна» - еще одно упрощение процедур торговли, которое воплотили уже многие страны. Наибольший эффект внедрения «единого окна» проявляется при его использовании для организации работы в морских портах.

Пункт 4 ст. 10 Соглашения об упрощении процедур торговли устанавливает, что члены должны активно создавать или сохранять пункты, принимающие документы по принципу «единое окно», и/или требования к данным при оформлении импорта, экспорта или транзита, а также упрощать процедуры 
таким образом, чтобы информация, предоставленная через «единое окно», не запрашивалась повторно другим пограничным ведомством, включенным в тот же пункт «единого окна». Кроме того, пункты «единого окна» в странах-участницах должны, где это возможно и целесообразно, использовать в таких пунктах электронный документооборот.

Члены должны стремиться создать или поддерживать «единое окно», позволяющее участникам ВЭД предоставлять участвующим органам или ведомствам документацию и (или) требуемые данные для ввоза, вывоза либо транзита товаров через единый пропускной канал. После проверки документов и данных участвующими органами или ведомствами результаты должны быть своевременно доведены до сведения заявителей через «единое окно».

Внедрение концепции «единого окна» обсуждается не один год как на уровне Российской Федерации, так и на уровне Таможенного союза. Сейчас Дорожная карта «Совершенствование таможенного администрирования» содержит лишь пункт, предусматривающий межведомственное электронное взаимодействие, но только в части обмена информацией о выданных разрешительных документах. На уровне Таможенного союза также обсуждается и планируется внедрение системы «единого окна» для трех стран-участниц на основе Интегрированной информационной системы внешней и взаимной торговли. Внедрению механизма «единого окна» посвящено, в частности, решение Высшего Евразийского экономического совета от 29 мая 2014 г. № 68.

Сегодня одна и та же информация для каждого государственного органа представляется отдельно, часто в разных форматах. В таможенный орган одна и та же информация может представляться несколько раз на разных этапах таможенного оформления: при прибытии товара, при временном хранении, транзите и декларировании товаров. Документы, которые требуют государственные контролирующие органы, на $80 \%$ содержат повторяющиеся данные. По оценкам экспертов, количество требуемых документов в наших морских портах достигает 64-77 форм в четырех-пяти экземплярах. Национальные «единые окна» - системы, позволяющие всем своим пользователям (государственным органам и участникам ВЭД) осуществлять все действия, установленные национальным законодательством в сфере регулирования импортно-экспортных операций, представляя все необходимые документы и сведения один раз в единый орган или единую автоматизированную систему. Согласно отчету Всемирного банка по международной торговле за 2012 г. система национального «единого окна» действует в 49 государствах.

Внедрение технологии «единого окна» предусмотрено Планом по улучшению ситуации в морских портах, утвержденным распоряжением Правительства РФ № 739-Р от 30 апреля 2014 г. 
Технология «единого окна» призвана ускорить информационные потоки между государственными органами и участниками ВЭД и за счет этого сократить их обоюдные издержки. В частности, участники ВЭД выигрывают от ускорения таможенной очистки и получения разрешения на отгрузку своего товара, благодаря чему сокращаются сроки поставки. Кроме того, благодаря тому, что в рамках «единого окна» происходит систематический сбор и обновление данных, применение механизма «единого окна» позволяет сделать процедуры торговли более простыми и безопасными. Кроме того, «единое окно» может предоставлять своим пользователям актуальную информацию об изменениях нормативных актов в области таможенно-тарифного регулирования, а также о ставках таможенных пошлин и сборов. Сбор, обработка и распространение информации с помощью «единого окна» позволит высвободить людские ресурсы, занятые в этой области в государственных или частных учреждениях, и тем самым сэкономить и направить их на решение иных задач и функций.

Внедрение электронного документооборота в рамках функционирования «единого окна» способствует снижению возможности проявления различных злоупотреблений и коррупции, так как сводит к минимуму непосредственное общение представителей государственных контролирующих органов и участников ВЭД.

Таким образом, краткий обзор лишь некоторых положений Соглашения об упрощении процедур торговли наглядно демонстрирует, что воплощение и имплементация предусмотренных в нем мер в законодательство и практику таможенных органов России и других государств - членов Таможенного союза позволит существенным образом снизить издержки у участников ВЭД.

Однако остаются некоторые вопросы, пока имеющие теоретический характер о соотношении положений Соглашения об упрощении процедур торговли и других международных норм в области таможенного дела, прежде всего Международной конвенции об упрощении и гармонизации таможенных процедур, о правовом статусе обязательств членов Соглашения.

В заключение следует отметить, что снижение административных барьеров для осуществления торговых операций, особенно в нынешней экономической ситуации, окажет позитивное воздействие на положение многих компаний. Вне зависимости от вступления Соглашения в силу российские регуляторы могли бы использовать его положения уже сегодня для настройки институтов таможенного администрирования в целях содействия торговле. 
Balandina G. ${ }^{1}$

\section{Facilitating trade or simplifying border procedures}

The article is devoted to the Agreement on Trade Facilitation (TFA) approved by the 9-th WTO Ministerial Conference and accepted in December 2014 by the WTO General Council. The TFA is analyzed in detail including its significance for improvement of custom system of Russia, Byelorussia and Kazakhstan as well as problems and difficulties related to implementation of the agreement in under the existing circumstances.

Key words: trade facilitation, customs regulations, transit, customs rules, WTO.

1 Balandina Galina Vladimirovna - senior researcher Institute of Applied Economic Studies of Russian Presidential Academy of National Economy and Public Administration (RANEPA). 